\title{
DETERMINAN MARGIN KEUNTUNGAN \\ PRODUK PEMBIAYAAN MURABAHAH
}

\author{
Fachri Maulida Rabbani \\ PT. Summit OTO Finance \\ Fachrijanujaz19@gmail.com \\ Nawirah \\ Universitas Islam Negeri Maulana Malik Ibrahim Malang \\ nawirah@uin-malang.ac.id
}

\section{Abstract}

Murabahah financing product at PT. Pegadaian Syariah branch Landungsari Malang, Murabahah Logam Mulia untuk Investasi Abadi (MULIA) is defined as a gold trade financing in a cash or credit in accordance with Sharia laws. This research aims at exploring the determination process of profit margin and the implementation of Standard Operating Procedure in the practice of murabahah financing at PT. Pegadaian Syariah branch of Landungsari Malang. This study uses qualitative method with two approaches. First, the researcher conducted an observation and in-depth interview to Strategi Bisnis Unit (SBU) assistant manager. The result of this study confirms that researcher get total of profit margin $R p .85 .414$ in which there is administration cost Rp. 50.000, sales margin 2,5\% Rp. 15.725, and installment margin 3,94\% namely Rp. 24.783. Researcher get discount margin Rp. 5.094 that's means net installment margin is Rp. 19.689. The determination of profit margin for murabahah financing has considered the terms of sharia laws by using consensus principle which is mentioned in Quran surah An Nisa verse 29. This verse explains that any transaction should not bother customers. With this basis, therefore, the practice of murabahah financing has been compatible with the regulations written on Standard Operating Procedure of the firm.

Keywords: Murabahah; Margin; Standard Operating Procedure.

\section{Abstrak}

Produk pembiayaan pada PT. Pegadaian Syariah Cabang Landungsari Malang, Murabahah Logam Mulia untuk Investasi Abadi (MULIA) merupakan jual beli pembiayaan dalam bentuk tunai maupun kredit sesuai prinsip Islam. Penelitian ini bertujuan untuk mengetahui faktorfaktor yang mempengaruhi margin keuntungan serta penerapan syariah pada Standar Operasional Prosedurnya. Penelitian ini menggunakan metode kualitatif dengan dua pendekatan yaitu observasi dan wawancara 
mendalam. Hasil penelitian ini mengkonfirmasi bahwa peneliti mendapatkan margin keuntungan penjualan sebesar 2,5\% dan margin installment sebesar 3,94\%. Penentuan margin keuntungan pada pembiayaan murabahah ini telah mempertimbangkan nilai Islam dengan berpedoman pada Q.S. An Nisaa ayat 29. Oleh karena itu, penerapan Standar Operasional Prosedur telah mempraktekkan prinsip-prinsip syariah.

Kata kunci: Murabahah; Margin; Standar Operasional Prosedur

\section{PENDAHULUAN}

Perkembangan lembaga keuangan syariah membawa dampak baik untuk perkembangan akuntansi syariah yang aplikatif sebagaimana dikembangkan untuk penyempurnaan akuntansi syariah yang sudah ada saat ini (Wiroso, 2010: 15). Akuntansi Syariah mempunyai pengertian yang sama dengan akuntansi konvensional tetapi yang membedakan adalah syariat Islam menjadi dasar hukum dalam menjalankan akuntansi syariah. Akuntansi syariah memiliki tujuan dalam pengakuan, pengukuran, pencatatan transaksi, dan pengungkapan hak-hak serta kewajiban secara adil tanpa mengurangi sedikitpun hak-hak atau kewajiban orang lain. Sebagaimana firman Allah SWT surat An-Nahl yang mengharuskan bahwa setiap muslim harus berlaku adil, Allah berfirman :

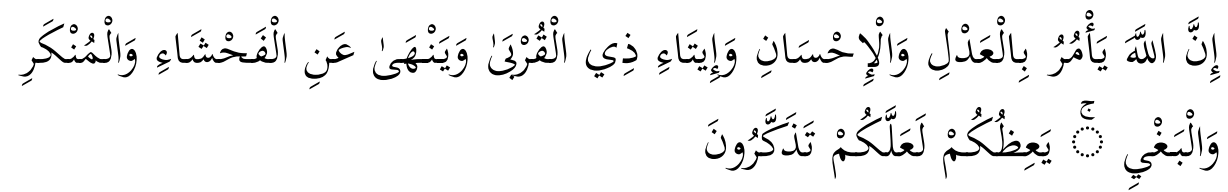

"Sesungguhnya Allah menyuruh (kaum) berlaku adil dan berbuat kebajikan" (Q.S An Nahl 16:90).

Keberadaan lembaga keuangan syariah di Indonesia merupakan alternatif yang positif ditengah-tengah keberadaan Bank Konvensional yang menguasai aktivitas perekonomian di Indonesia. Lembaga keuangan syariah menjanjikan suatu sistem operasional yang lebih ada khususnya pada sistem bagi hasil keuntungan, jika lembaga keuangan konvensional menerapkan sistem bunga maka lembaga keuangan syariah menerapkan sistem bagi hasil. Karena bagi lembaga keuangan syariah bunga bank merupakan sesuatu yang diharamkan oleh Allah SWT. 
Antonio (2010: 7) menyatakan bahwa produk bagi hasil seperti Mudharabah dan Musyarakah pada lembaga keuangan syariah masih termajinalkan sehingga pembiayaan yang banyak diminati masyarakat adalah pembiayaan jual beli barang dengan sistem harga Mark up yang dikenal dengan Murabahah. Menurut PSAK No. 102 Murabahah merupakan akad jual beli barang dengan harga jual sebesar biaya perolehan ditambah keuntungan yang disepakati. Penjual harus mengungkapkan biaya perolehan barang tersebut kepada pembeli.

Transaksi murabahah di lembaga keuangan syariah menempati porsi yang sangat besar dibandingkan pembiayaan lainnya. Pada tahun 2017 prosentase pembiayaan murabahah mencapai hingga 60\% di lembaga keuangan syariah di Indonesia (Saparie, 2017). Prosentase yang besar tidak menjamin praktik murabahah sudah dijalankan dengan baik, masih terdapat banyak kritikan-kritikan terhadap praktik murabahah yang memiliki kendala dalam hal menentukan margin keuntungan yang merujuk kepada suku bunga bank konvensional. Kondisi seperti ini mengindikasikan adanya sebuah persepsi yang kurang baik terhadap produk lembaga keuangan syariah.

Berdasarkan penjelasan diatas maka betapa pentingnya mengetahui proses penentuan margin keuntungan pada produk murabahah di lembaga keuangan syariah agar terlepas dari persepsi yang buruk bagi lembaga keuangan syariah itu sendiri. Maka peneliti tertarik melakukan penelitian dengan mengambil judul "Analisis Penentuan Margin Keuntungan Pada Produk Pembiayaan Murabahah di PT. Pegadaian Syariah Cabang Landungsari Kota Malang”.

\section{KAJIAN PUSTAKA}

Lembaga keuangan syariah memiliki karakteristik yang tidak dimiliki oleh lembaga keuangan konvensional dari segi prinsip bagi hasil. Dalam prinsip bagi hasil, pembagian keuntungan tidak boleh berasal dari ketentuan satu pihak. Lembaga keuangan syariah tidak pernah membayarkan bagi hasil kepada pemilik dana lebih besar dari pendapatannya. Bagi hasil yang dibayarkan merupakan bagian dari pendapatan utama. 
Murabahah merupakan jual beli dengan adanya informasi harga pokok dari pihak penjual, harga jual merupakan penambahan harga pokok dengan tingkat margin keuntungan yang disepakati (Djuwaini, 2010 : 104). Murabahah merupakan produk pembiayaan yang diberikan oleh lembaga keuangan syariah kepada nasabah yang membutuhkan barang dengan kriteria yang diinginkan. Lembaga keuangan syariah berposisi bukan sebagai penjual barang yang memproduksi barang sendiri melainkan menjadi media perantara ke pihak ketiga sebagai pihak pemasok barang yang dipesan dari nasabah, dan juga lembaga keuangan syariah bukan juga sebagai penyedia dana kepada nasabah.

Murabahah merupakan salah satu jual beli dengan akad saling percaya dan ridho, informasi harga pokok dan margin keuntungan harus diketahui dan disepakati oleh kedua belah pihak. Rasulullah SAW pernah bersabda dalam hadits dari riwayat Abu Sa'id Al-Khudri bahwa "Sesungguhnya jual beli itu harus dilakukan dengan asas suka sama suka." (HR. Al Baihaqi, Ibnu Majah, dan Shahih menurut Ibnu Hibban).

Pembiayaan Murabahah di Indonesia diatur dalam Fatwa Dewan Syariah Nasional Majelis Ulama Indonesia Nomor 04/DSN-MUI/IV/2000 tentang murabahah. Regulasi Fatwa DSN-MUI bertujuan untuk menentukan keabsahan dalam melaksanakan pembiayaan murabahah.

Akuntansi pembiayaan murabahah diatur dalam Pernyataan Standar Akuntansi Keuangan (PSAK) No. 102. Berdasarkan PSAK No. 102 paragraf 06-17 menyatakan bahwa murabahah dapat dilakukan dengan pesanan maupun tanpa pesanan, penjual melakukan pembelian barang dari pemasok setelah ada pesanan dari pembeli.

Pembiayaan murabahah dapat dilakukan secara tunai maupun angsuran. Akad harga jual murabahah menerangkan bahwa hanya ada satu harga yaitu harga jual pada padas saat akad yang digunakan. Jika murabahah dilakukan secara kredit/tangguh maka penjual berhak meminta uang muka kepada pembeli sebagai bukti komitmen pembelian pada saat terjadinya akad. Uang muka menjadi bagian pelunasan dari piutang murabahah.

Wiroso (2010: 74) mengemukakan para pernyataan Ulama Kontemporer dalam hal terbentuknya suatu pembiayaan murabahah harus memenuhi rukun dan syarat sesuai syariat Islam. Rukun 
Fachri Maulida: Determinan Margin Keuntungan

Murabahah terdiri dari: 1) Adanya penjual (ba'i); 2) Adanya pembeli (musytari); 3) Adanya objek barang (mabi); 4) Harga (tsaman); dan 5) Adanya Ijab Kabul (Sighat). Sementara itu, syarat murabahah ialah:

a) Pembiayaan murabahah bukan pinjaman uang yang diberikan dengan bunga, tetapi merupakan pembiayaan yang bersifat jual beli barang dengan harga pokok ditambah margin keuntungan yang disepakati.

b) Lembaga Keuangan Syariah sebagai pemberi pembiayaan sebelumnya harus membeli barang dari pihak ketiga sebagai pemasok sebelum dijual kepada nasabah.

c) Pembelian barang tidak boleh diikuti dengan perjanjian pembelian kembali (buy back).

d) Penjual harus menjelaskan kepada pembeli bila terjadi cacat atas barang sesudah pembelian

e) Penjual harus menyampaikan semua hal terkait dengan pembelian.

Ridho (2009: 49) menyatakan bahwa penetapan harga jual merupakan sebuah proses dalam menentukan berapa yang harus diterima perusahaan untuk setiap produk yang dijualnya. Penetapan harga jual di dalamnya meliputi harga pokok barang yang dibeli, keuntungan yang diinginkan, serta biaya-biaya yang dikeluarkan untuk mendapatkan barang tersebut. Metode penetapan harga jual memiliki 3 metode yaitu:

1. Metode Cost Plus Pricing, yaitu metode menentukan harga jual dengan cara harga pokok ditambah dengan margin keuntungan diatas biaya-biaya yang dikeluarkan untuk memperoleh sebuah barang.

2. Metode Market Based Pricing, yaitu metode menentukan harga jual berdasarkan harga pasar sehingga produk yang dijual dapat bersaing di pasaran dengan mempertimbangkan respon pelanggan terhadap harga yang diberikan.

3. Metode Contribution Pricing, yaitu metode menentukan harga jual diatas biaya-biaya yang dikeluarkan tetapi juga mempertimbangkan harga jual dipasaran. 
Menurut informasi dari redaksi@tazkiaonline.com margin merupakan kenaikan bersih dari aset akibat dari memegang kuasa aset yang mengalami peningkatan nilai. Keuntungan juga bisa diperoleh dari pemindahan barang saling tergantung insidental yang sah dan yang tidak saling tergantung, kecuali transfer yang tidak tergantung pada pemegang saham atau pemegang-pemegang rekening investasi lainnya yang setara dengannya.

Pengertian margin berdasarkan Kamus Besar Bahasa Indonesia Pusat Bahasa adalah laba kotor atau tingkat selisih antara biaya perolehan/produksi dan harga jual". Margin keuntungan adalah prosentase yang ditetapkan secara fleksibel bisa ditentukan secara tahunan, harian, maupun bulanan. Berdasarkan definisi diatas maka dapat disimpulkan bahwa margin adalah prosentase tingkat selisih yang mengalami peningkatan nilai dari biaya perolehan/biaya produksi dan harga jual.

Lembaga keuangan syariah dalam praktiknya sering sekali meninggikan dalam menentukan margin keuntungan yang bertujuan untuk mengantisipasi inflasi. Penetapan margin keuntungan yang tinggi secara tidak langsung akan menyebabkan inflasi yang lebih besar dari suku bunga, maka perlu dicari sousi yang tepat agar nilai penjualan dengan pembiayaan murabahah tidak mengacu pada sikap untuk mengantisipasi kenaikan suku bunga selama masa pembayaran angsuran (Muhammad, 2005: 140).

Penentuan harga menurut syariat hukum Islam harus dengan adanya keridhoan dan prinsip suka sama suka, karena prinsip ini bertujuan untuk menghormati hak kepemilikan umatnya. Allah mengharamkan kepada umatnya untuk mengambil hak saudara sesama muslim dengan cara yang bathil. Al Qur'an surat An-Nisa ayat 29 telah mengatur bahwa murabahah/jual beli harus disertai kerelaan, Allah SWT berfirman:

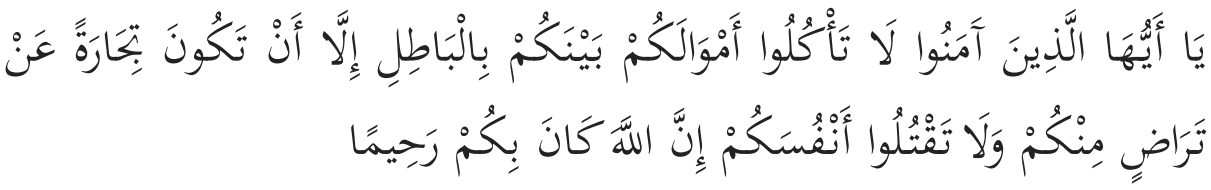

"Hai orang-orang yang beriman, janganlah kamu saling memakan harta sesamamu dengan jalan yang batil, kecuali dengan jalan perniagaan yang 
Fachri Maulida: Determinan Margin Keuntungan

berlaku dengan suka sama suka diantara kamu. Dan janganlah kamu membunuh dirimu sendiri, sesungguhnya Allah adalah Maha Penyayang kepadamu" (QS. An-Nisa (4) : 29)

Produk-produk berbasis syariah di Pegadaian Syariah memiliki karakteristik dasar yaitu tidak memungut bunga dalam bentuk apapun karena bunga merupakan transaksi riba' yang diharamkan oleh syariat Islam. Produk murabahah di Pegadaian Syariah dikenal dengan nama MULIA (Murabahah Logam Mulia Untuk Investasi Abadi). Produk MULIA dapat didefinisikan sebagai layanan jual beli emas batangan kepada masyarakat secara tunai maupun angsuran dengan proses yang mudah dan jangka waktu yang fleksibel (http://www.pegadaian.co.id/ pegadaian-mulia.php).

Produk pembiayaan MULIA bertujuan untuk membantu nasabah untuk kepemilikan emas sebagai komoditi atau investasi dengan cara tunai maupun angsuran. Ada 3 pihak yang terkait di dalam pelaksanaan produk pembiayaan MULIA, yaitu pihak penjual (Pegadaian Syariah), pihak pembeli (nasabah), dan pemasok (PT. ANTAM). Pegadaian Syariah menjual emas berdasarkan pesanan dari nasabah dengan harga pokok pasaran emas yang bisa diakses lewat web resmi Pegadaian atau lewat web resmi jual beli emas. Pada awal transaksi harga pokok dan margin keuntungan diketahui nasabah. Jika transaksi dilakukan secara angsuran maka nasabah diwajibkan membayarkan uang muka dan biaya administrasi atas persetujuannya akad murabahah. Nasabah diwajibkan menyerahkan emas sebagai barang jaminan sampai angsuran dilunasi karena pembiayaan dilakukan secara angsuran mengingat emas merupakan barang dengan nilai ekonomis yang tinggi.

\section{METODE PENELITIAN}

Lokasi yang dipilih dalam penelitian ini adalah PT. Pegadaian Syariah Cabang Landungsari Kota Malang. Penelitian ini merupakan jenis penelitian kualitatif yang bertujuan meneliti subjek secara alami tanpa adanya manipulasi. Peneliti menggunakan pendekatan fenomenomlogi instrumentalisasi (Posfenomenologi). Posfenomenologi merupakan penelitian bedasarkan fenomena yang terjadi dengan menggunakan kebenaran empiris semata untuk mendapatkan pengetahuan 
Fachri Maulida: Determinan Margin Keuntungan

(Kamayanti, 2016: 161). Hal ini bertujuan untuk mengetahui bagaimana praktik di lapangan dalam penentuan margin keuntungan pada pembiayaan murabahah di PT. Pegadaian Syariah Cabang Landungsari Kota Malang. Data yang dipaparkan bersifat faktual dan naturalistik dengan kondisi yang sebenarnya.

Subyek yang peneliti pilih dalam penelitian ini adalah orang yaitu bapak Dinal selaku Asisten Manajer Divisi SBU Syariah PT. Pegadaian Syariah (Persero). Tempat yang menjadi subyek dalam penelitian ini adalah PT. Pegadaian Syariah Cabang Landungsari Kota Malang. Adapun benda dalam penelitian ini adalah semua bukti transaksi yang penelitian lakukan terkait pembiayaan MULIA di PT. Pegadaian Syariah Cabang Landungsari Kota Malang.

Penelitian melakukan observasi dan wawancara dalam melakukan teknik pengumpulan data. Observasi dilakukan dengan cara melakukan transaksi langsung produk MULIA di PT. Pegadaian Syariah Cabang Landungsari Kota Malang. Wawancara dilakukan kepada bapak Dinal selaku asisten manajer SBU Syariah PT. Pegadaian (Persero) untuk mengetahui bagaimana proses penentuan margin keuntungan produk MULIA.

Analisis data merupakan proses sistematis pencarian dan pengaturan transkrip wawancara, catatan lapangan, dan data-data yang telah dikumpulkan untuk meningkatkan pemahaman mengenai materimateri pada topik permasalahan dalam penelitian (Emzir, 2010:85). Data yang telah dikumpulkan secara lengkap dan telah di cek keasliannya serta dinyatakan valid lalu diproses melalui langkah-langkah yang bersifat umum, kemudian penelitian melakukan analisis atas datadata tersebut.

Data-data yang di dapatkan dari observasi dan wawancara kemudia diolah serta dimanfaatkan sedemikian rupa. Sehingga data-data tersebut dapat menyimpulkan kebenaran-kebenaran guna menjawab permasalahan yang dibahas dalam penelitian ini. analisis data digunakan untuk mengetahui antara kebijakan dan praktik lapangan terkait menentukan margin keuntungan produk MULIA di PT. Pegadaian Syariah Cabang Landungsari Kota Malang. 


\section{HASIL DAN PEMBAHASAN}

\section{Paparan Data Hasil Penelitian}

Pegadaian Syariah di Indonesia didirikan atas dasar menjawab semua keinginan umat Islam di Indonesia untuk melaksanakan transaksi mu'mallah berdasarkan prinsip-prinsip hukum Islam. Pegadaian Syariah memiliki tujuan untuk meningkatkan kepercayaan masyarakat dalam hal pemberian pembiayaan berdasarkan hukum syariat Islam. Pegadaian memiliki produk murabahah yang dikenal dengan nama MULIA (Murabahah Logam Mulia Untuk Investasi Abadi). Produk MULIA merupakan produk pembiayaan logam emas mulia yang diberikan kepada masyarakat guna memenuhi kepemilikan emas dengan metode pembayaran secara tunai maupun angsuran.

Akad menurut terminologi Islam adalah ikatan antara penyerahan (ijab) dan penerimaan (qobul) yang dibenarkan dalam Islam serta harus ada dalam setiap pelaksanaan transaksi. Dalam pelaksanaannya produk MULIA di Pegadaian Syariah akad yang utama menggunakan akad murabahah. Tetapi jika pembiayaan MULIA dilakukan secara angsuran maka akan terjadi akad rahn setelah akad murabahah disetujui.

Akad rahn dilakukan untuk menyimpan barang yang dibeli nasabah karena mengingat obyek barang adalah emas yang memiliki nilai estetis yang tinggi. Akad rahn juga bertujuan untuk menghindari kelalaian nasabah dalam hal membayar angsurannya. Emas yang dititipkan melalui akad rahn baru bisa diambil nasabah jika nasabah dapat melunasi angsurannya sesuai dengan jangka waktu yang telah disepakati. Kedua akad ini tidak dilaksanakan bersama-sama karena Rasulullah SAW melarang adanya dua akad yang dilakukan bersamasama dalam satu transaksi. Ketentuan syariat Islam tentang adanya jaminan dalam pembiayaan murabahah diatur dalam fatwa Dewan Syariah Nasional Majelis Ulama Indonesia Nomor 25/DSN-MUI/III/2002.

Pegadaian Syariah sebagai pihak penjual barang yang dibeli dari pemasok yaitu PT. ANTAM setelah ada pesanan dari pihak kedua yaitu nasabah. Pembiayaan MULIA di Pegadaian Syariah memberikan proses yang cepat dan fleksibel dalam jangka waktu tertentu. Adapun persyaratan dan prsedur menurut Standar Operasional Produk Pembiayaan MULIA, antara lain: 
Persyaratan Pengajuan Pembiayaan MULIA.

1. Menyerahkan foto copy KTP atau tanda pengenal lain yang masih berlaku

2. Menyerahkan foto copy kartu keluarga bagi perseorangan

3. Menyerahkan foto copy NPWP dan foto copy AD/ART (Anggaran Dasar/Anggaran Rumah Tangga) bagi yang mengajukan atas nama badan usaha.

4. Mengisi formulir persetujuan Pembiayaan MULIA dan menandatanganinya

5. Menandatangani akad murabahah dan akad rahn (jika dilakukan secara kredit) pada Form Akad MULIA

6. Menyerahkan uang muka sesuai kesepakatan 10-90\% (jika angsuran)

7. Membayar uang administrasi sebesar Rp. 50.000

\section{Prosedur Pengajuan Pembiayaan MULIA}

1. Nasabah datang ke outlite Pegadaian Syariah dengan maksud melakukan jual beli emas logam dengan pembiayaan MULIA

2. Nasabah mengajukan KTP dan KK yang masih berlaku serta membawa sejumlah uang untuk uang muka

3. Petugas menyerahkan formulir persetujuan Pembiayaan MULIA

4. Selain itu, petugas menanyakan berapa uang muka yang akan dibayarkan dan membuatkan bukti pembayaran uang muka untuk pembelian emas

5. Apabila pembelian dilakukan secara tangguh dan angsur, maka kemudian petugas membuatkan form perjanjian akad MULIA yang didalamnya terdapat dua akad, yaitu akad murabahah dan akad rahn.

6. Kedua belah pihak menandatangi perjanjian dan emas logam MULIA akan diterima nasabah setelah melunasi hutang pembeliannya.

Standar Opersional Prosedur produk pembiayaan MULIA mengklasifikasi terdapat 2 margin keuntungan dalam produk pembiayaan MULIA yaitu margin penjualan dan margin angsuran. Menurut pak Dinal selaku asisten manajer SBU Syariah PT. Pegadaian Syariah menyatakan bahwa margin penjualan merupakan margin yang 
Fachri Maulida: Determinan Margin Keuntungan

wajib diberikan ke nasabah atas transaksi pembiayaan MULIA, sedangkan margin angsuran diberikan karena nasabah melakukan pembiayaan MULIA secara angsuran. Adapun ketentuan produk pembiayaan MULIA menurut Standar Operasional Prosedur adalah :

Tabel 1. Ketentuan Pembiayaan MULIA

\begin{tabular}{|l|l|l|}
\hline No. & \multicolumn{1}{|c|}{ Aspek } & \multicolumn{1}{c|}{ Keterangan } \\
\hline 1 & Logam Mulia & Logam Mulia cap ANTAM atau Pegadaian \\
\hline 2 & Jangka Waktu & a. 3 Bulan \\
& & b. 6 Bulan \\
& & c. $\quad$ 12 Bulan \\
& & d. 18 Bulan \\
& & e. $\quad$ 24 Bulan \\
\hline 3 & Uang Muka & $20-40 \%$ \\
\hline 4 & Akad Pembiayaan & Murabahah \\
\hline 5 & Biaya Administrasi & Rp. 50.000 \\
\hline 6 & Margin Penjualan & $2,5 \%$ \\
\hline 7 & Margin Angsuran & $4 \%, 6 \%, 12 \%, 36 \%$ \\
\hline 8 & Cara Pembayaran & Angsuran/Tunai \\
\hline
\end{tabular}

Sumber : Pedoman Operasional Pegadaian Syariah Produk Pembiayaan MULIA

\section{Pembahasan Penelitian}

Mekanisme pembiayaan MULIA dimulai dari peneliti sebagai pihak kedua yaitu sebagai pembeli yang mendatangi pihak pertama sebagai penjual yaitu PT. Pegadaian Syariah Cabang Landungsari Kota Malang dengan membeli emas seberat 1 gr dengan akad murabahah secara kredit selama 3 bulan. Kemudian PT. Pegadaian Syariah Cabang Landungsari Kota Malang membeli emas sesuai kriteria pesanan nasabah dari pihak pemasok yaitu PT. ANTAM. Selanjutnya PT. ANTAM memberikan barang sesuai dengan pesanan ke PT. Pegadaian Syariah Cabang Landungsari Kota Malang. Lalu PT. Pegadaian Syariah Cabang Landungsari Kota Malang memberikan barang tersebut ke nasabah dengan harga jual dari harga pokok ditambah margin keuntungan setelah nasabah melunasi angsuran murabahah. Untuk lebih memahami alur mekanisme pembiayaan MULIA dapat dilihat pada gambar 1.

Peneliti melakukan transaksi langsung pembiayaan MULIA dengan akad murabahah di PT. Pegadaian Syariah Cabang Landungsari Kota Malang pada tanggal 5 Desember 2017. Peneliti membeli logam 
emas mulia seberat 1 gr secara kredit dengan harga pokok pada 5 Desember 2018 sebesar Rp. 629.000. PT. Pegadaian Syariah Cabang Landungsari Kota Malang memberikan total margin kepada peneliti sebesar Rp. 85.414. Total margin keuntungan tersebut didalamnya terdapat biaya administrasi sebesar Rp. 50.000, margin penjualan 2,5\% sebesar Rp. 15.725, sedangkan margin angsuran 3,94\% didapat sebesar Rp. 24.784. Peneliti mendapatkan diskon atas margin angsuran sebesar Rp. 5.094. sehingga margin angsuran yang wajib dibayarkan peneliti tersisa Rp. 19.689.

(1)

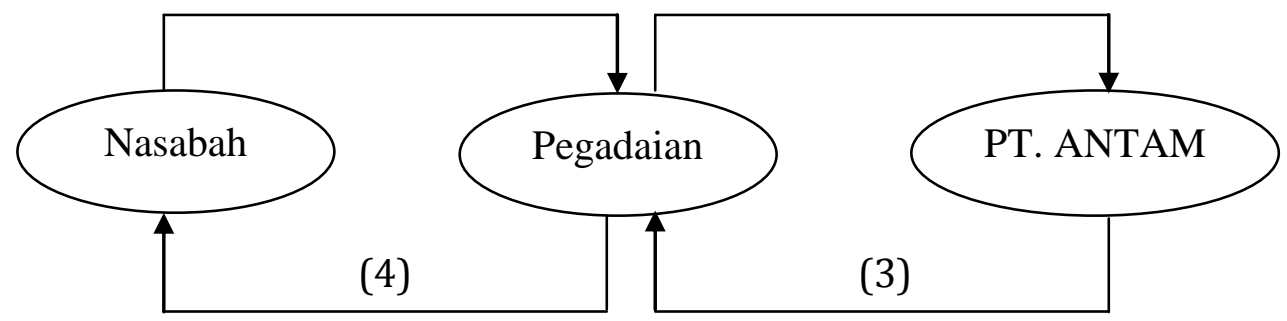

Gambar 1. Mekanisme Pembiayaan MULIA

(Sumber : Data Diolah 24 April 2018)

Peneliti membayar uang muka sebesar Rp. 194.990 untuk menyatakan bahwa bersungguh-sungguh melakukan pembiayaan MULIA. Uang muka tersebut dibayarkan atas uang muka murni sebesar Rp. 129.265, biaya administrasi Rp. 50.000 dan margin penjualan Rp. 15.725. Margin penjualan dibayarkan diawal pada saat akad karena margin penjualan merupakan margin tunai yang harus dibayarkan nasabah saat pelaksanaan akad pertama.

Sisa hutang setelah peneliti membayar uang muka ialah sebesar Rp. 519.424 yang didalamnya terdapat hutang murni sebesar Rp. 499.735 dan margin angsuran 3,94\% sebesar Rp. 19.689. Peneliti melakukan pembiayaan MULIA dengan jangka waktu 3 bulan dengan angsuran per-bulan sebesar Rp. 173.143. Peneliti membeli emas secara kredit sehingga peneliti harus menyimpan barangnya di PT. Pegadaian Syariah Cabang Landungsari Kota Malang sampai utang angsuran peneliti dilunasi. Penyimpanan barang dilakukan dengan menggunakan akad rahn. 
Fachri Maulida: Determinan Margin Keuntungan

Dari pembahasan yang peneliti lakukan berdasarkan data saat transaksi langsung, peneliti dapat menganalisis dengan menjadikan Standar Operasional Prosedur pembiayaan MULIA sebagai acuan sebagai berikut:

Tabel 2. Implementasi Standar Operasional Prosedur dengan Penerapan di Lapangan Produk Pembiayaan MULIA

\begin{tabular}{|l|l|l|l|}
\hline No & Aspek & $\begin{array}{l}\text { Standar Operasional } \\
\text { Prosedur }\end{array}$ & $\begin{array}{l}\text { Penerapan } \\
\text { Lapangan }\end{array}$ \\
\hline 1 & Logam Mulia & $\begin{array}{l}\text { Logam MULIA Cap } \\
\text { ANTAM atau Pegadaian } \\
\text { fineness 99,9\% }\end{array}$ & $\begin{array}{l}\text { Logam MULIA } \\
\text { ANTAM 99, } \\
\text { Fineness }\end{array}$ \\
\hline 2 & Jangka Waktu & $\begin{array}{l}\text { a. 3 Bulan } \\
\text { b. 6 Bulan } \\
\text { c. 12 Bulan } \\
\text { d. 18 Bulan }\end{array}$ & 3 Bulan \\
& & $\begin{array}{l}\text { e. 24 Bulan } \\
\text { f. 36 Bulan }\end{array}$ & \\
\hline 3 & Uang Muka & $20-40 \%$ & $27 \%$, Rp. 194.990 \\
\hline 4 & Akad Pembiayaan & Murabahah & Murabahah \\
\hline 5 & Biaya Administrasi & Rp. 50.000 & Rp. 50.000 \\
\hline 6 & Margin Penjualan & $2,5 \%$ & $2,5 \%$, Rp. 15.725 \\
\hline 7 & Margin Angsuran & $4 \%$ & $3,94 \%$, Rp. 24.783 \\
\hline 8 & Cara Pembayaran & Angsuran/Tunai & Angsuran \\
\hline
\end{tabular}

Sumber Data Diolah 24 April 2018

Penerapan Standar Operasional Prosedur penentuan margin produk pembiayaan MULIA berdasarkan penjelasan analisis diatas memiliki kesesuaian dengan praktik di lapangan dari beberapa aspek. Margin penjualan ditetapkan 2,5\% sebesar Rp. 15.725 sedangkan margin angsuran sebesar 3,94\% sebesar Rp. 24.783, peneliti mendapatkan diskon margin angsuran sebesar Rp. 5.094 sehingga sisa margin angsuran sebesar Rp. 19.689 .

Hikmah dari bermurabahah adalah penjual harus jujur memberikan setiap informasi berkenaan dengan biaya-biaya yang harus dibayarkan peneliti. Penetapan harga dalam Islam tidak ditentukan secara spesifik dengan nominal tetapi harus dilakukan dengan keridhoan satu sama lain. Yang paling penting dari murabahah adalah kejujuran penjual sebagaimana hadits Rasulullah SAW : 


$$
\begin{aligned}
& \text { بيع المرابحة جائز من غير كراهة وهو عقد يبنى الثمن فيه على ثمن المبيع الأول مع } \\
& \text { زيادة بأن يشتري شيئاً بمائة ثم يقول لغيره بعتك هذا بما اشتريته وربح درهم زيادة أو } \\
& \text { بربح درهم لكل عشرة أو في كل عشرة }
\end{aligned}
$$

"Hukum transaksi jual beli murabahah adalah boleh tanpa adanya unsur makruh. Murabahah merupakan akad yang dibangun dengan jalan menetapkan harga suatu barang diatas harga belinya ditambah keuntungan. Misalnya seseorang membeli barang dengan harga 100 kemudian berkata kepada pihak kedua, aku jual barang ini ke kamu sesuai dengan harga dasar aku membelinya ditambah laba sekian dirham sebagai laba, atau dengan laba sekian dirham untuk tiap-tiap 10 dirhamnya atau tiap 10 persennya" (H.R. Imam Al Mawardi, al-Iqna' fii Hillil Alfadh Abi Sujja'[1/468]).

Murabahah secara tangguhan merupakan jenis mu'amalah yang diberkahi oleh Allah SWT, sebagaimana hadits Rasulullah SAW :

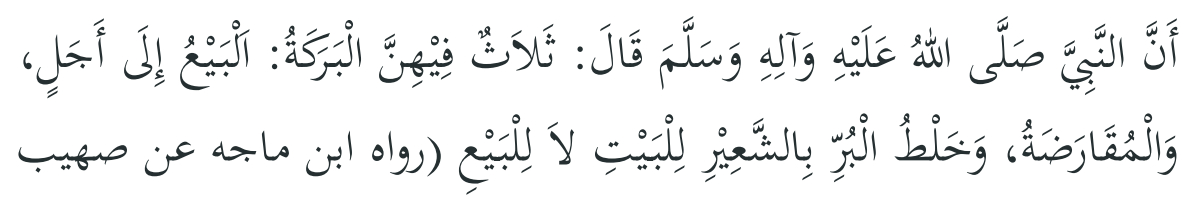

"Rasulullah SAW bersabda: Tiga hal yang didalamnya terdapat keberkahan antara lain ; jual beli secara tangguh (murabahah), muqaradhah (mudharabah), dan mencampur gandum dengan tepung untuk kepentingan rumah tangga bukan untuk dijual" (HR. Ibnu Majah).

Emas yang merupakan barang ribawi mengindikasikan akan terjadi praktik riba' karena hukum mu'amallah emas tidak boleh dilakukan secara kredit jika barang yang ditukar dengan emas juga termasuk dalam kategori barang ribawi. Tetapi peneliti melakukan transaksi emas secara kredit dengan menggunakan uang yang diberlakukan sebagai alat pembayaran. Menurut ijma ulama fiqih kontemporer mata uang selain dinar dan dirham bukan merupakan barang ribawi (Azza, 2013:50).

Di Indoensia murabahah emas secara tangguhan sudah ditetapkan bukan merupakan praktik riba' lewat Fatwa Dewan Syariah Nasional Majelis Ulama Indonesia Nomor : 77/DSN-MUI/V/2010. Jadi bermurabahah emas secara tidak tunai hukumnya boleh selagi penjual 
Fachri Maulida: Determinan Margin Keuntungan

dan pembeli sama sama mengikuti syarat dan ketentuan ber-murabahah yang telah ditetapkan oleh hukum Islam.

\section{KESIMPULAN}

Praktik penentuan margin keuntungan yang dijalankan PT. Pegadaian Syariah Cabang Landungsari Kota Malang telah diterapkan berdasarkan aturan Standar Operasional Prosedur perusahaan. Terdapat 2 margin yang diberikan Pegadaian Syariah kepada nasabah yaitu margin penjualan dan margin angsuran. Harga pokok emas pada saat terjadi nya transaksi diketahui oleh pembeli dan bahkan pembeli bisa mengetahui harga pokok emas lewat web resmi Pegadaian. Jadi tidak ada unsur gharar atau ketidakjelasan dalam bertransaksi pembiayaan MULIA di Pegadaian Syariah.

Transaksi pembiayaan MULIA dengan akad murabahah di Pegadaian Syariah sudah memenuhi ketentuan syariat Islam. Hal ini dikarenakan peneliti dan Pegadaian Syariah menerapkan prinsip suka sama suka dalam menentukan harga. Pegadaian Syariah menerapkan prinsip Rasulullah SAW saat berdagang yaitu dengan memberikan penjelasan tentang harga pokok dan biaya-biaya yang harus dikeluarkan nasabah.

Praktik pembiayaan MULIA bukan termasuk transaksi riba' karena dari segi barang maupun harga sudah jelas. Murabahah emas yang dilakukan Pegadaian Syariah sudah diperbolehkan oleh Dewan Syariah Nasional Majelis Ulama Indonesia dengan keluarnya Fatwa Nomor : 77/DSN-MUI/V/2010

\section{DAFTAR PUSTAKA}

Al Qur'an dan Terjemahannya

Antonio, Muhammad Syafi'i. 2001. Bank Islam: Dari Teori Ke Praktek. Jakarta : Gema Insani Pres

Atmaja, Nur Kholis Kusuma. 2014. Analisis Penentuan Tarif Potongan Ijarah Dan Perlakuan Akuntansi Atas Pembiayaan Ijarah Oleh Perum Pegadaian Syariah Cabang Malang. Skripsi: Universitas Islam Negeri Maulana Malik Ibrahim Malang

Azza, Mudaimullah. 2013. Metodologi Fiqih Muamalah. Kediri: Lirboyo Press

Djuwaini, Dimyaudin. 2010. Pengantar Fiqih Muamalah. Yogyakarta: Pustaka Pelajar. 
Fachri Maulida: Determinan Margin Keuntungan

Efferin, Sujoko., Darmadji, Stevanus Hadi., Tan, Yuliawati. 2008. Metode Penelitian Akuntansi. Yogyakarta: Graha Ilmu.

Emzir. 2010. Metode Penelitian Kualitatif Analisis Data. Jakarta: Rajagrafindo Persada

Fatwa Dewan Syariah Nasional Nomor : 77/DSN-MUI/V/2010

Ikatan Akuntansi Indonesia. 2013. Pernyataan Standar Akuntansi Keuangan Nomor 102 Tentang Murabahah. Edisi Revisi. Jakarta: Salemba Empat

Kamayanti, Ari. 2016. Metode Penelitian Kualitatif Akuntansi. Malang: Ngapurancang

Muhammad. 2005. Manajemen Pembiayaan Bank Syariah. Yogyakarta: Akademi Manajemen Perusahaan YKPN.

Pedoman Operasioal Pegadaian Logam MULIA. Devisi Litbang dan Pemasaran PT. Pegadaian (Persero).

Rahmawati, Fithria Aisyah. 2015. Analisis Faktor yang Mempengaruhi Penetapan Margin Pada Pembiayaan Murabahah di BMT SeKabupaten Jepara. Jurnal Penelitian: EQUILIBRIUM, Vol. 3, No.2 Desember 2015.

Ridho, Ahmad. 2009. Skripsi: Analisis Faktor-Faktor Internal dan Eksternal yang Mempengaruhi Penetapan Margin Murabahah Untuk Produk Pembiayaan Pemilikan. Skripsi : Universitas Islam Negeri Syarif Hidayatullah Jakarta.

Saparie, Gunoto. 28 Agustus 2017. Dominasi Murabahah di Bank Syariah. Diperoleh tanggal 02 April 2018 Jam 19.30 dari https://indonesiana.tempo.co/read/115875/2017/08/28/guno tosaparie/

Sjahdeini, Sutan Remi. 2014. Perbankan Syariah Produk-Produk dan Aspek-Aspek Hukumnya. Jakarta: Kencana.

Wiroso. 2011. Akuntansi Transasksi Syariah. Jakarta: Ikatan Akuntan Indonesia

http://www.pegadaian.co.id/pegadaian-mulia.php.

www.redaksi@tazkiaonline.com 